\title{
Nutritional Value of Midday Meals of Senior Schoolchildren
}

\section{P. RICHARDSON, M. LAWSON}

British Medical fournal, 1972, 4, 697-699

\section{Summary}

A survey of 565 senior schoolchildren showed that $41 \%$ took the school meal. It provided $27 \%$ of the daily recommended energy intake and $35 \%$ of the daily protein intake set by the Department of Health and Social Security. Of the children who did not take the school meal $4 \%$ had a meal which compared favourably with it, though an equal number ate no lunch at all. The remainder either brought snacks from home or bought foods which were found to be both low in protein, iron, and calcium, and high in sugar. Sweets and chips provided the main source of energy for $9 \%$ of the subjects.

\section{Introduction}

The survey was undertaken during January and February 1972 at a large comprehensive school in London. The purpose was to find the source, the nutritional value, and the cost of the midday meal of senior schoolchildren.

\section{Methods}

On three separate visits a total of 565 children at a large comprehensive school in London were asked to complete a questionnaire. They were asked to state in some detail exactly what they had eaten during the Junch break, where it had been obtained, and how much it had cost. They completed the questionnaires immediately after the lunch break under the supervision of experienced teachers during their house meetings. All the children responded very intelligently, and excellent cooperation was obtained from the teaching staff. Of the total school population aged between 11 and 18 years, $29 \%$ filled in the questionnaire.

The school provides a choice of meals. At least three main dishes and two puddings are normally available as well as salads. The children select and pay for their meals on a day-today basis. On each of the three survey days samples of the school meal available were taken for analysis of energy, protein, and fat. Total energy was found using the bomb calorimeter (Miller and Payne, 1959). Total nitrogen was measured by the Kjeldahl method and fat was determined by the Soxhlet extraction.

Representative samples of all the foods which the children obtained from sources outside the school were collected and weighed. Their energy and nutrient contents were calculated from the food composition tables (McCance and Widdowson, 1960) programmed on the Queen Elizabeth College computer, and the nutrient content of the school meal was also estimated by computer.

\section{Results}

Information was obtained from the questionnaire on the source of the midday meal. The results are shown in Table I. Alto-

Department of Nutrition, Queen Elizabeth College, London W.8 D. P. RICHARDSON, B.SC., M.SC., Lecturer M. LAWSON, M.SC., Postgraduate Research Student
TABLE I-Source of Midday Meal of 565 Schoolchildren Aged 11-18 years

\begin{tabular}{|c|c|c|c|c|c|c|c|}
\hline & & & & & \multicolumn{2}{|c|}{ No. of Schoolchlidren } & \multirow[b]{2}{*}{ Total (\%) } \\
\hline \multicolumn{5}{|c|}{ Source of Food } & Boys & Girls & \\
\hline $\begin{array}{l}\text { School meal } \\
\text { Meal at home } \\
\text { Food bought } \\
\text { Food brought } f \\
\text { Nothing }\end{array}$ & $\begin{array}{cc}\because & \cdots \\
\because & \cdots \\
\text { from home } \\
\ldots & \ldots\end{array}$ & $\begin{array}{l}. . \\
\because \\
\cdots\end{array}$ & $\begin{array}{l}\cdots \\
\cdots \\
\cdots\end{array}$ & $\begin{array}{l}\cdots \\
\cdots \\
\cdots\end{array}$ & $\begin{array}{r}138 \\
8 \\
90 \\
37 \\
16\end{array}$ & $\begin{array}{r}94 \\
13 \\
86 \\
75 \\
8\end{array}$ & $\begin{array}{r}41 \\
4 \\
31 \\
20 \\
4\end{array}$ \\
\hline
\end{tabular}

gether, $41 \%$ of the subjects took the school meal, $31 \%$ bought food outside the school, $20 \%$ brought food from home, $4 \%$ lunched at home, and $4 \%$ ate nothing at all. Fewer girls than boys had a school meal and twice as many girls as boys brought food from home. In the school as a whole an average of $31 \%$ of the children had the school meal during January and February.

Although most schoolchildren took the school meal, further analysis of the data showed a change in lunch time habits with increasing age (see Chart). There is a definite fall in the uptake of school meals from nearly $60 \%$ at the age of 11 to below $20 \%$ at the age of 16. A reciprocal upward trend is shown in the consumption of food bought outside the school.

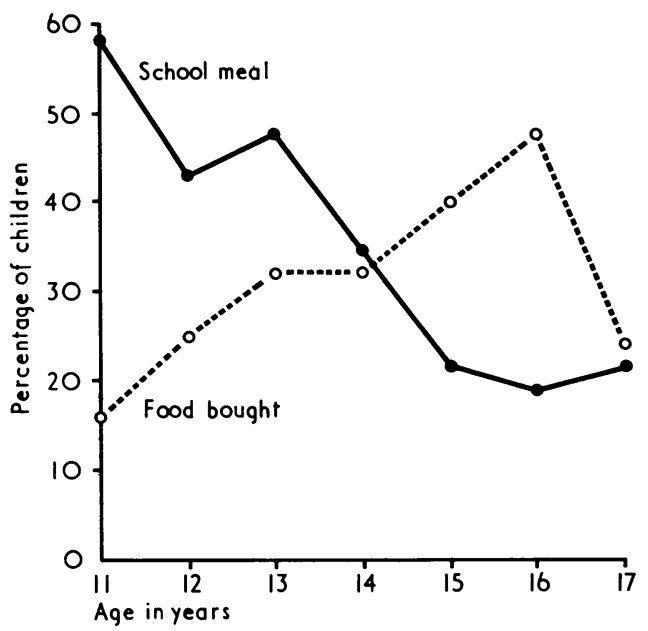

Uptake of school meal with age and percentage of children buying food.

The median (and range) of energy, protein, and sugar intakes obtained from the different sources are given in Table II.

It can be seen that of all the meals available the school meal provided the most energy and protein. Children who ate at home had a meal which compared favourably with the school meal though contributing fewer calories.

Although concern is expressed here for those who ate no lunch, attention was concentrated on the large proportion of children who either brought snacks from home or bought food

TABLE II-Mean Energy, Protein, and Sugar Consumption (Range in Parentheses)

\begin{tabular}{|c|c|c|c|c|c|}
\hline \multicolumn{3}{|c|}{ Source of Food } & \multirow{2}{*}{$\begin{array}{c}\text { Energy (kcal) } \\
680(400-1,120) \\
555(260-1,160) \\
680(90-2,980) \\
440(150-1,250)\end{array}$} & \multirow{2}{*}{$\begin{array}{l}\text { Protein }(\mathrm{g}) \\
20(8-39) \\
19(10-47) \\
15(2-76) \\
11 \quad(3-40)\end{array}$} & Sugar (g) \\
\hline $\begin{array}{l}\text { School meal } \\
\text { Meal at home } \quad \ldots \\
\text { Food bought } \quad \ldots \\
\text { Brought from home }\end{array}$ & .. & $\begin{array}{l}\because \\
\because \\
\cdots\end{array}$ & & & $\begin{array}{ll}19 & (13-66) \\
19 & (0-130) \\
29 & (0-160) \\
12 & (0-150)\end{array}$ \\
\hline
\end{tabular}


outside the school. In the last two categories the protein intake was much lower than that available from the school meal.

The energy consumption varied enormously, and analysis of the results showed that children who bought their midday meal had excessive sugar intakes associated with the less nutritious high carbohydrate snacks and beverages.

Iron and Calcium Intakes.-The intakes of iron and calcium (median and range) are given in Table III. Daily recommended intakes for children 12-18 years are 14-15 mg of iron and 600-700 $\mathrm{mg}$ of calcium. The school meal provided $4.3 \mathrm{mg}$ of iron and $170 \mathrm{mg}$ of calcium, representing $30 \%$ and $26 \%$ respectively of the daily recommended intakes. The children who brought food from home obtained the least amount of iron and also low intakes of calcium.

TABLE III-Mean Iron and Calcium Intakes (Range in Parentheses)

\begin{tabular}{|c|c|c|c|c|}
\hline Source of Food & $\begin{array}{l}\text { Iron } \\
\text { (mg) }\end{array}$ & $\begin{array}{c}\% \text { of } \\
\text { Recommended } \\
\text { Daily } \\
\text { Allowance* }\end{array}$ & $\underset{(\mathrm{mg})}{\text { Calcium }}$ & $\begin{array}{c}\% \text { of } \\
\text { Recommended } \\
\text { Daily } \\
\text { Allowance* }\end{array}$ \\
\hline $\begin{array}{l}\text { School meal } \\
\text { Meal at home } \ldots \\
\text { Food bought } \ldots \\
\text { Brought from home }\end{array}$ & $\begin{array}{l}4 \cdot 3(2 \cdot 5-5 \cdot 7) \\
4 \cdot 2(0 \cdot 8-11 \cdot 1) \\
3 \cdot 1(0 \cdot 2-4 \cdot 2) \\
2 \cdot 1(0 \cdot 2-7 \cdot 1)\end{array}$ & $\begin{array}{l}30 \\
29 \\
21 \\
14\end{array}$ & $\begin{array}{l}170(90-490) \\
200(80-720) \\
110(20-690) \\
120(0-930)\end{array}$ & $\begin{array}{l}26 \\
30 \\
17 \\
18\end{array}$ \\
\hline
\end{tabular}

*Recommended Daily Allowance for boys and girls 12-15 years (Department of Health and Social Security, 1969).

TABLE IV-The School Meal

\begin{tabular}{|c|c|c|c|c|}
\hline & & \multicolumn{3}{|c|}{ Mean Energy and Protein Content } \\
\hline & & Energy (kcal) & Protein (g) & Fat $(g)$ \\
\hline $\begin{array}{l}\text { Analysed } \\
\text { Computed }\end{array}$ & $\begin{array}{ll}. & . \\
. & .\end{array}$ & $\begin{array}{l}700 \\
730\end{array}$ & $\begin{array}{l}23 \\
14\end{array}$ & $\begin{array}{l}29 \\
32\end{array}$ \\
\hline
\end{tabular}

The analysed and computed values for energy and protein are given in Table IV. The amount of protein was found to differ because coding of the school meal for the computer did not allow for the amount of dried milk added to the custard. About one-third of the protein content of the school meal is supplied in this way. Those children getting the dried milk would also receive a supplement providing over a third of the daily recommended intake of calcium.

The present standards for the school meal are laid down by the Department of Education and Science (1966). School meals are intended to provide $880 \mathrm{kcal}, 29 \mathrm{~g}$ of protein and $32 \mathrm{~g}$ of fat. The average analysed values for the school meal reached $80 \%$ of the energy and protein targets and $90 \%$ of the fat target set by the Department of Education. Expressed in terms of daily recommended allowances this represents $27 \%$ of the recommended energy intake and $35 \%$ of the protein intake.

In an attempt to trace any vulnerable groups by their nutrient intake it was found that sweets or chips provided the main source of energy for $9 \%$ of the subjects. The nutrient intakes of these children are given in Table $\mathrm{V}$.

TABLE v-Nutrient Intakes (Median and Range) of Children Whose Energy Source was Predominantly Sweets and Chips

\begin{tabular}{|c|c|c|c|c|c|c|}
\hline & & \multicolumn{5}{|c|}{ Nutrient Intake } \\
\hline & & $\begin{array}{c}\text { Energy } \\
\text { (kcal) }\end{array}$ & $\begin{array}{l}\text { Protein } \\
\text { (g) }\end{array}$ & $\underset{(\mathrm{g})}{\text { Sugar }}$ & $\begin{array}{l}\text { Iron } \\
(\mathrm{mg})\end{array}$ & $\underset{(\mathrm{mg})}{\text { Calcium }}$ \\
\hline $\begin{array}{l}\text { Sweets } \\
\text { Chips .. }\end{array}$ & $\ddot{x}$ & $\begin{array}{l}300(110-800) \\
450(90-1,500)\end{array}$ & $\begin{array}{l}3(0-11) \\
8(0-11)\end{array}$ & $\begin{array}{l}46(16-90) \\
18(0-120)\end{array}$ & $\begin{array}{l}0.9(0-4 \cdot 2) \\
2 \cdot 8(1-11 \cdot 5)\end{array}$ & $\begin{array}{l}90(0-290) \\
65(20-370)\end{array}$ \\
\hline
\end{tabular}

Carbohydrate supplied over $60 \%$ of the energy intake of these children, with protein contributing on average less than $6 \%$. Iron and calcium intakes were correspondingly low.

In addition to the children who ate nothing at all (4\%) a further $2 \%$ had only fruit or a drink. In each case such foods provided less than $100 \mathrm{kcals}$.

Cost.-A school meal cost 12 pence at the time of the study.
The children who bought their own food spent on average 19 pence. No attempt was made to cost the meals taken at home or the snacks brought from home. The average additional expenditure during lunch time-that is, the amount spent on ice-creams, sweets, etc.-was in the case of a school meal $5 \cdot 2 \mathrm{p}$, a meal at home $5 \cdot 5 p$, and food brought from home $6 \cdot 7 p$.

\section{Discussion}

The survey indicates that most of the children obtained a satisfactory midday meal, but attention is drawn to those who were eating inadequate lunches and in particular those who bought food. The diets recorded by these children often showed excessive intakes of sweets, cakes, and soft drinks.

During adolescence the nutrient requirements are conditioned by a period of rapid growth and development beginning at puberty. At a time when the physical and mental demands of the individual are sharply increased, the provision of sufficient of the necessary foods at meal times becomes more critical. In particular, the children bringing food from home or buying food obtained relatively little protein, calcium, or iron from their midday meal. Protein and calcium have a special significance for the adolescent as components of new body tissue and developing bones. The iron intakes suggest that iron deficiency anaemia may occur in some cases, but clinical evidence would have been required to confirm these suspicions.

No information was obtained on the adequacy of the children's other meals or whether the type of midday meal reflected the usual pattern of eating. From the results there was no indication of undernutrition but it is possible that mineral deficiencies may occur if the requirements are not met from other sources. Many young people are apt to skip meals. Bender et al. (1972) found that $7 \%$ of the children went to school without breakfast, and G. W. Lynch (1972, personal communication) indicated the figure to be as high as 1 in 5 . This survey found $4 \%$ of the children went without food at lunch time and that it is relatively simple for those habitually skipping meals and eating poor lunches to have excessive sugar intakes through the consumption of high carbohydrate snacks and beverages.

The children showed enormous variation in their energy consumption. Nine of them had, at lunch time, estimated calorie intakes of above $1,500 \mathrm{kcals}$. Whether the energy output of these children was in balance cannot be judged without measuring their individual energy requirements. No information on heights and weights of the children was obtained, nor whether they regarded themselves overweight or underweight.

A survey in a London secondary school by Mortimer (1968) showed that $8 \%$ of the girls aged between 11-16 years were in need of treatment for obesity. In a Californian study of teenagers, Hampton et al. (1967) found that the energy consumption of the obese was less than average though they ate less frequently and were more likely to miss meals. In the present survey nearly half the girls were interested in slimming, and $27 \%$ were actively seeking to lose weight.

Sugar.-Sugar is a source of "empty calories" and a factor in promoting tooth decay. Its use is therefore discouraged, particularly among children. Excessive intakes of sugar were found among the children who bought food, nearly half of whom chose sweets. The median sugar intake from the school meal was $19 \mathrm{~g}$, which compares closely with $18 \mathrm{~g}$ suggested by the Department of Education and Science-that is, sugar provides $11 \%$ of the calories. The children who bought food obtained $17 \%$ of their energy from sugar, whereas for 25 children eating mostly sweets, sugar supplied $61 \%$ of their energy intake. Bender et al. (1972) in a survey of 48 schools in Southeast England showed that the energy and protein content of the school meals fell short of the standards set by the Department of Health and Social Security. This survey has shown that improvements in the school meal itself would be justified, but from the nutritional point of view it still offers the best value for money. 
We are extremely grateful to the headmaster, staff, and pupils of the school, and to the Inner London Education Authority, for allowing the survey to take place.

\section{References}

Department of Education and Science (1966). Nutritional Standard of School Dinners. Circular 3/66. London, H.M.S.O.
Department of Health and Social Security (1969). Recommended Intakes of Nutrients for the United Kingdom. Report No. 120. London, H.M.S.O. McCance, R. A., and Widdowson, E. M. (1960). Composition of Foods. Medical Research Council. Special Report Series, No. 297.

Miller, D. S., and Payne, P. R. (1959). British fournal of Nutrition, 13, 501. Miller, D. S., and Mumford, P. (1970). Proceedings of Nutrition Society, 29, 116. Bender, A. E., Magee, P., and Nash, A. H. (1972). British Medical fournal,

Mortimer, P. M. (1968). Proceedings of the Nutrition Society, 27, 29.

Hampton, M. C., Huenemann, R. L., Shapiro, L. R., and Mitchell, B. W. (1967). Fournal of the American Dietetic Association, 50, 385.

\title{
Effects of Oestrogen on Urinary Thyroxine Excretion
}

\author{
VIVIAN CHAN， G. M. BESSER， J. LANDON
}

British Medical fournal, 1972, 4, 699-701

\begin{abstract}
Summary
The day to day variation and the effects of oestrogen on the urinary excretion of thyroxine ( $T-4)$ were studied in euthyroid women and men. Serial urinary $T-4$ values over a period of 28 consecutive days were found to lie within relatively narrow limits except for a transient increase during menstruation in women. During oestrogen therapy urinary $T-4$ was unchanged, but an appreciable rise was seen after stopping oral ovulation inhibitors in women. A similar effect was seen in men after three days' treatment with $20 \mu \mathrm{g} /$ day of ethinyloestradiol. The increased urinary $T-4$ excretion on oestrogen withdrawal reached a maximum in one to three days. This response contrasted with that produced by phenytoin, a drug known to bind to thyroxine binding globulin, and which resulted in increased urinary $T-4$ excretion during the period that it was being administered.
\end{abstract}

\section{Introduction}

Increased levels of oestrogen in the blood, whether of exogenous or endogenous origin, have profound effects on thyroid function tests. Heinemann et al. (1948) were the first to report that serum protein bound iodine (P.B.I.) increased in pregnancy and Engstrom and his colleagues (1952) found that this could be induced in non-pregnant women by oestrogen administration. The rise in P.B.I. levels is accompanied by a shift in the uptake of triiodothyronine ( $\mathrm{T}-3)$ by the patient's serum or red cells into the hypothyroid range (Hollander et al., 1963; Winikoff and Taylor, 1966). Both effects can be attributed to an increase in certain serum proteins and their capacity to bind thyroid hormones (Dowling et al., 1956; Engbring and Engstrom, 1959; Tata, 1960; Florsheim and Faircloth, 1964). Clark and Horn (1965) introduced the free thyroxine (T-4) index, calculated from the P.B.I. and T-3 uptake results, to correct for changes in these serum levels. Circulating T-3 levels also increase during pregnancy (Hotelling and Sherwood, 1971) despite the fact that it is less avidly bound by thyroxine binding proteins as compared with T-4. Other thyroid parameters which are influenced by the administration of oral ovulation inhibitors include the

St. Bartholomew's Hospital, London E.C.1

VIVIAN CHAN, M.SC., Biochemist, Department of Chemical Pathology G. M. BESSER, M.D., M.R.C.P., Senior Lecturer in Endocrinology, The Medical Professorial Unit

J. LANDON, M.D., M.R.C.P., Professor of Chemical Pathology secretion of thyroid stimulating hormone (Fisher and D'angelo, 1971; Galton, 1971), thyroidal 131I uptake (Kennedy et al., 1964; Boccabella and Alger, 1964), the T-4 half-life (Engbring and Engstrom, 1959), and circulating free T-4 concentration (Arango et al., 1968; Rosenbaum et al., 1968; Fang and Selenkow, 1970; Malkasian and Mayberry, 1970). The latter is of particular interest as it is regarded as the biologically active fraction, and thus reflects the true thyroid status of the individual.

The present study was undertaken to assess the effects of oestrogen on urinary T-4 excretion, as it has been suggested that the latter relates directly to the serum free T-4 concentration (Chan and Landon, 1972). Serial urinary T-4 values over a period of 28 days were studied in euthyroid men and women, and compared with those in women receiving oral contraceptives. The effects of ethinyl oestradiol and of phenytoin administration on urinaty $\mathrm{T}-4$ excretion in healthy euthyroid men were also investigated.

\section{Subjects and Methods}

A total of 66 volunteers were studied, comprising 34 healthy ambulant subjects, 20 euthyroid inpatients, and 12 women receiving oral ovulation inhibitors.

Urine was collected from each subject over a single 24-hour period, together with a $12-\mathrm{ml}$ blood sample. Further urine collections were made for 28 consecutive days in three groups of healthy volunteers aged 20 to 30 . The groups comprised five men, five women, and five women who had been receiving oral ovulation inhibitors containing either $50 \mu \mathrm{g}$ per tablet of ethinyloestradiol or mestranol for periods of four to 36 months.

A further nine healthy euthyroid male volunteers were studied to determine the effect of ethinyloestradiol on urinary T-4, serum total T-4, and T-3 uptake. Samples were collected for a three to five-day control period during the three days they received ethinyloestradiol ( $20 \mu \mathrm{g}$ daily) and for four to six days afterwards.

The effects of phenytoin on thyroid function were also studied in one healthy euthyroid man. Samples were collected for a three-day control period during the four days of phenytoin medication and for a further two days after cessation of therapy.

Blood samples were separated within two hours of venepuncture and the serum stored at $-20^{\circ} \mathrm{C}$ until required for assay. The determination of serum P.B.I. by a Technicon automated method, and a total T-4 and T-3 uptake by a Sephadex equilibration technique, was performed as described previously (Chan and Landon, 1972; Chan et al., 1972).

Urinary T-4 estimations were made using duplicate 3-ml aliquots of urine according to the method described previously (Chan and Landon, 1972). This involved acidification of the urine sample, solvent extraction, and determination of T-4 content of the extract by saturation analysis. 